\title{
Successful Factors of Implementation Electronic Customer Relationship Management (e-CRM) on E-commerce Company
}

\author{
Trinh Le Tan ${ }^{1}$, Dao Thi Dai Trang ${ }^{2}$ \\ ${ }^{1}$ International School, Duy Tan University, Da Nang, Vietnam \\ ${ }^{2}$ Department of Account, Duy Tan University, Da Nang, Vietnam
}

Email address:

Letandtu@gmail.com (T. Le Tan), Daitrangdtu@gmail.com (D. T. Dai Trang)

To cite this article:

Trinh Le Tan, Dao Thi Dai. Successful Factors of Implementation Electronic Customer Relationship Management (e-CRM) on E-commerce Company. American Journal of Software Engineering and Applications. Vol. 6, No. 5, 2017, pp. 121-127. doi: 10.11648/j.ajsea.20170605.12

Received: September 12, 2017; Accepted: September 23, 2017; Published: November 7, 2017

\begin{abstract}
Advancement IT encourage a change of human behaviour in the shopping, especially in the online store/ecommerce. The objective of this study is to determine the successful indicators of e-CRM implementation in the e-commerce company. This study uses the descriptive method with Library Research approach by looking at the results of some previous journal and using three indicators: customer complaint, customer loyalty and implementation control management e-CRM. The result is every indicator can be a benchmark for successful e-CRM implementation in the e-commerce. But, there is no relevant journal that combines the three indicators by doing a thorough investigation. This study only summarizes the results of any previous journals which discuss indicators that affected to e-CRM implementation.
\end{abstract}

Keywords: E-commerce, E-CRM, Customer Complaint, Customer Loyalty, Implementation Control Management e-CRM

\section{Introduction}

Globalization era become the era of information technology advances where every man can getting information quickly and accurately. Seeing a business opportunity from advancement of information technology, ecommerce systems were created. E-commerce is a process of purchasing and selling goods online or allows producers and consumer do not meet directly to do the transaction.

E-commerce competition between businessmen for winning over prospective customers can be done in various ways, such as compete by displaying a competitive price, performing a variety of attractive promotions, and provide the best service at the time the goods on offer. Various strategies undertaken by businessmen make prospective consumers have many options to buy products that comply with the wishes.

The problems that occurred in the purchase and sale transactions with e-commerce are the customer complaints on services delivered, delays in delivery, product quality is not as expected, and other errors that peeved consumers. Various problems occurred resulting in changes in consumer behavior. A growing number of customer complaints about their dissatisfaction in purchasing and selling on e-commerce website, resulting in a decreasing customer loyalty and tends to affect others to not make purchasing and selling on that ecommerce website. This requires an integrated system to facilitate customer in the filing of the complaint, as well as creating the best service standards in dealing with customer complaints to strengthen relations producers and consumers. IT-based systems that are used to address these problems is the Electronic Customer Relationship Management (e-CRM).

Customer Relationship Management (CRM) is a business strategy undertaken by the company to maintain a good relationship with the consumer in order to increase customer loyalty. Atul \& Jagdish (2004) stated that CRM is a comprehensive, strategy and process of acquiring, retaining, and partnering with selective customers to create superior value for the company and the customer, such as involves the integration of pre-sales, customer service and the supplychain functions of the organization to achieve the greater efficiencies and effectiveness in delivering customer value. 
Therefore, any all lies of business must implement CRM to maintain the company's relationships with its customers.

At first, the CRM implementation is manual and do not require IT intervention because companies still make a direct purchasing and selling by meeting between the seller and the buyer (the market share is still small). However, this time along with the rapid development of information technology allows each company to expand its market share by selling goods online. Therefore, adopting CRM strategy information technology systems to facilitate any companies or lines of business to organize the all needs in customer service, both service while sale takes place or service if the customer complaint occurs. Therefore, CRM is an important strategy that provides a rich proactive and reactive communication channel ( $\mathrm{Wu}$ 2013). Thus, it is recommended that online retailers adopt the e-CRM such as a call center system that handle queries from various channels such as e-mail, telephone, fax and the Internet (Kim and Eom 2002). It is well advised that online retailers need to have enough staff members to answer customers' diverse questions via telephones and e-mails or utilize the e-CRM applications as discussed earlier (Jun et al. 2004). Some companies view CRM primarily as investments in technology and software, whereas others treat CRM more expansively and are aggressive in developing sound and productive relationships with customers. In addition, some companies have implemented CRM processes to a greater degree than others (Reinartz et al. 2004).

In this study, the author will discuss the implementation of e-CRM in based e-commerce company or online shop, where customer satisfaction with the services offered, and the number of customer complaints as a benchmark of the eCRM success. The problem research of this study is "Does the customer complaint, customer loyalty, and implementation control management e-CRM determine the success of e-CRM implementation in e-commerce company?"

\section{Literature Review}

\subsection{E-Commerce Development}

In order to meet the community needs quickly, the information required must also be fast. Therefore the use of internet technologies nowadays has become an absolute necessity for almost everyone. The development of the use of the internet has expand to business, namely e-commerce. The definition of e-commerce itself is the electronic process by which individuals or organizations make transaction, such a buy, sell, transfer, or exchange product, service and/or information (Turban et al. 2004). E-commerce offers potential benefits in the form of enhanced participation in international value chains, increased market access and reach, and improved internal and market efficiency, as well as lower transaction costs.

E-commerce can cover purchases and sales conducted over computer networks, using multiple formats and devices, including the web and electronic data interchange, using personal computers, laptops, tablets and mobile phones of varying levels of sophistication. And e-commerce may involve physical goods as well as intangible (digital) products and services that can be delivered digitally. These benefits make e-commerce more and more as well as rapidly growing in online business.

There are four types of e-commerce, those are B2B (Business-to-Business), B2C (Business-to-Consumer) and C2C (Consumer-to-Consumer). B2B encompasses all electronic transactions of goods or services conducted between companies. One of the example of e-commerce is online shop that which included into the type B2C ecommerce. Online shop is very popular and growing very rapidly in Indonesia even in the world. Many conveniences offered by online shop-such as categories of products very diverse, wide range of goods delivery, amount of media that can be used to sell, and providing interesting promos-makes consumers prefer to shopping online compared to traditional stores. Online shopping is a complex process that can be divided into various sub-processes such as navigation, searching for information, online transactions, or customer interactions.

Transactions that occur in the online shop starts when the customer visiting the online shop that usually a website or blog. Furthermore, customers will find the desired item by category or certain specific characteristics. Once customers find the items they want, then customer doing the payment transactions. This payment can be made by transfer, using credit card etc. And the last stage of the business process is the process of verification of the payment and delivery of goods to customers. Additional stages are usually as followup service complaints, repeat orders, etc occurs when the customer was not satisfied with the service or goods purchased.

Judging from the number of online shopping enthusiasts who take advantage of the ease of transactions, the effectiveness and efficiency of shopping, as well as cheaper prices, it is certain that the level of transactions online shop is very high compared to traditional stores. On the other hand, although online transactions increases, the rate of online fraud was also increased. The example of fraud is the order is not delivered or delivered but defective, counterfeit or not in accordance with the order. The rise of online fraud making consumers angry and also make the seller feel aggrieved. Consumers become afraid to shop online, thus slowing the development of their business. An American study revealed that of the 5,000 people who make online purchases, a third of them claimed to reduce the amount or value of their purchase. The main reason is because the issue of security is still a concern. If we looking to measure the e-commerce readiness of countries. It discusses the main factors facilitating and constraining e-commerce - with an emphasis on B2C transactions - such as Internet connectivity, payment systems and delivery systems.

The treatment that e-commerce companies and online shop gives is the key of customer loyalty to the company. The level of customer loyalty can be seen from the level of visits 
on the website, the number of sales transactions and the repurchase rate from the customer. If the rate of visits an ecommerce website is high, it means that the website interesting enough to get the attention of prospective customers. Similarly, if the number of transactions that occur on the website is high, then it indicates the company's ecommerce can be trusted and relied upon as a place where customers can get a wide range of goods they need. But if the high level of sales transaction and customer visits that are not accompanied with good customer service, it is possible that e-commerce will lose the customer. A good customer service is to satisfy the customer, provide solutions to customer complaints presented and should give faster feedback responses in an accurate and kindly manner.

\section{2. $E-C R M$}

CRM is an integration of technologies and business processes used to satisfy the needs of a customer during any given interaction. More specifically, CRM involves acquisition, analysis and use of knowledge about customers in order to all more goods or services and to do it more efficiently (Bose 2002). CRM business philosophy relying on the understanding of the lifetime value of customers and provide personalized treatment as well as excellent service. Now, CRM has become a facility to gain knowledge as well as the entirety of the customer, which would allow companies to provide service according to the needs and behavior of customers.

CRM component framework classify into three (Kurniawan 2009) as following: (1) Operational CRM, known as the "front office" of the company. Operational CRM application have a role in the interaction with customers and it includes an integrated automation process of the entire business processes, such as marketing automation, sales, and service. The application example of CRM Operational is the form of web applications; (2) Analytical CRM, known as the "back office" of the company. This CRM application is play a role in understanding customer needs, for example is carrying out the analysis of customers and markets, such as the analysis of market trends and customer behavior analysis. Data used in Analytical CRM is the data derived from Operational CRM; (3) Collaborative CRM, including e-mail, personalized publishing, ecommunities, and the like which are designed for interaction between the customer and the organization. It main objective is to spread cheer and customer loyalty to other customers who are still not at the level of customer loyalty. Collaborative CRM also includes an understanding or awareness that loyal customers can be a magnet for other customers.

As a result of rapid development technology and information, now been widely used e-CRM as the latest developments from the usual CRM systems. E-CRM (Electronic Customer Relationship Management) is the application of Internet-based technologies such as emails, websites, chat rooms, forums and other channels to achieve CRM objectives. It is a well-structured and coordinated process of CRM that automates the processes in marketing, sales and customer service. E-CRM provides an avenue for interactions between a business, its customers and its employees through Web-based technologies.

A typical e-CRM strategy involves collecting customer information, transaction history and product information, click stream and contents information. It then analyzes the customer characteristics to give a transactional analysis consisting of the customer's profile and transactional history, and an activity analysis consisting of exploratory activities showing the customer's navigation, shopping cart, shopping pattern and more.

The benefits of e-CRM include the following:

Improved customer relations, service and support

Matching the customers' behavior with suitable offers

Increased customer satisfaction and loyalt

Greater efficiency and cost reduction

Increased business revenue

Businesses that strategize and implement an e-CRM solution are able to align their processes around technology to effectively deliver seamless, high-quality customer experience across all channels. Customers have the power to help themselves through online personalized services that are made available on demand. From the explanation above it can be said that the consumer is a major reason to implement e-CRM. Therefore, consumers should be treated and served very well to achieve customer satisfaction, even when post purchase. This all because the satisfied consumers are tend to be a loyal customer (Rosmala et al. 2012), and retain customers is one of the main focus in CRM. According to Ho and $\mathrm{Wu}$ (1999), things that make up the customer satisfaction are logistic support, technical characteristics, information characteristics, home page presentation and product characteristics.

One example of the businesses that implement e-CRM is an e-commerce. As a business that relies on the Internet, website and the speed of information, e-commerce requires a system that serves, organize and follow up on customer complaints effectively and efficiently so that all complaints can be dealt with quickly. This is one of the e-commerce effort to satisfy and retain customers so that the e-commerce credibility is maintained.

There are many indicators that can determine the success of the e-CRM implementation, such as customer loyalty, customer behavior, corporate value, sales rate, control of eCRM implementation, etc. This study using three indicators namely customer complaint, customer loyalty, and Implementation Control Management E-CRM. Table 1 contains several similar studies that include indicators of success e-CRM implementation in e-commerce company. 
Table 1. Indicators of the Successful E-CRM Implementation.

\begin{tabular}{|c|c|c|c|c|c|}
\hline Authors Name / & \multirow{2}{*}{ Purchases } & \multirow{2}{*}{$\begin{array}{l}\text { Repeat } \\
\text { Purchases }\end{array}$} & \multirow{2}{*}{$\begin{array}{l}\text { Customer } \\
\text { Satisfication }\end{array}$} & \multirow{2}{*}{$\begin{array}{l}\text { Customer } \\
\text { Complaints }\end{array}$} & \multirow{2}{*}{$\begin{array}{l}\text { E-CRM } \\
\text { Surveillance }\end{array}$} \\
\hline Descriptions & & & & & \\
\hline Cho et al. (2002) & 1 & 1 & - & 1 & 1 \\
\hline Shim et al. (2002) & 1 & - & 1 & - & 1 \\
\hline Ahmad (2002) & - & - & 1 & 1 & 1 \\
\hline Feinberg and Kadam (2002) & 1 & - & 1 & - & - \\
\hline Jun et al. (2004) & - & - & 1 & - & 1 \\
\hline Guang and Fen (2005) & 1 & 1 & 1 & 1 & 1 \\
\hline Bai et al. (2008) & 1 & 1 & 1 & - & - \\
\hline Hansen et al. (2010) & - & - & 1 & 1 & 1 \\
\hline Feng and Ming (2012) & 1 & 1 & 1 & - & 1 \\
\hline Farhadi et al. (2012) & - & - & 1 & - & - \\
\hline Long, Ing (2013) & - & - & 1 & 1 & 1 \\
\hline
\end{tabular}

Table 2. Selected Findings from Literature.

\begin{tabular}{|c|c|}
\hline Authors (year) & Significant Findings \\
\hline Ahmad (2002) & $\begin{array}{l}\text { Thid study finds that failure to institute adequate complaint management and service recovery systems contributed to customer } \\
\text { defection. }\end{array}$ \\
\hline Cho et al. (2002) & $\begin{array}{l}\text { This study found that the propensity to complain had a positive effect on repeat purchase intention both in the online and offline } \\
\text { environment, if the problem is resolved by the seller. }\end{array}$ \\
\hline $\begin{array}{l}\text { Lee-Kelly et al. } \\
(2003)\end{array}$ & $\begin{array}{l}\text { E-CRM implementation effort correlatives with the perceived degree of e-CRM receive, in turn is linked to the loyalty experienced } \\
\text { b virtual customer towards the e-retailer, and the relationship between customer loyalty and price sensitivity is weak. }\end{array}$ \\
\hline $\begin{array}{l}\text { Schoder \& Madeja } \\
(2004)\end{array}$ & $\begin{array}{l}\text { The successful implementation of e-CRM is by e-commerce is strongly influenced by company size, type of business, as well as } \\
\text { the ability of the management company itself. }\end{array}$ \\
\hline Bai et al. (2008) & $\begin{array}{l}\text { Website quality has a direct and positive impact on customer satisfaction, and that customer satisfaction has a direct and positive } \\
\text { impact on purchase intentions. }\end{array}$ \\
\hline $\begin{array}{l}\text { Guang and Fen } \\
(2010)\end{array}$ & $\begin{array}{l}\text { The dimensions of web site design, reliability, responsiveness, and trust affect overall service quality and customer satisfaction. } \\
\text { The latter in turn are significantly related to customer purchase intentions. The personalization dimension is not significantly } \\
\text { related to overall service quality and customer satisfaction. }\end{array}$ \\
\hline $\begin{array}{l}\text { Feng and Ming } \\
(2012)\end{array}$ & $\begin{array}{l}\text { Positive emotions increase post-recovery satisfaction, and vice versa. Post-recovery satisfaction positively affects post-purchase } \\
\text { intentions. }\end{array}$ \\
\hline Long (2013) & $\begin{array}{l}\text { Distributive and interactional justice contribute significantly to customer satisfaction and, in turn, to complaint intentions, but } \\
\text { procedural justice does not. }\end{array}$ \\
\hline
\end{tabular}

\section{Research Model}

This study uses the descriptive method with Library Research approach, which is a technique of data collection by conducting a study of books, literature, records, and reports relating to the topic raised (Nazir 1988). The object of this study is e-commerce company with a various business scale based on the results of several previous journals with the same topic.

Because this study uses the descriptive method, hence this study has no specific object nor sample data. The previous journals have not mentioned in detail the name of the ecommerce company or online shopping as an object, and most of them did not mention the e-commerce business scale either.

This study merely combines some previous research according to the selected findings in the literature above, as a research model. This model comes from a meta-analysis that has been done in order to look for indicators that can be used as a benchmark to determine the successful implementation of e-CRM in the e-commerce companies. And this research model facilitates the further researchers to perform analysis on relevant topics without having researching.

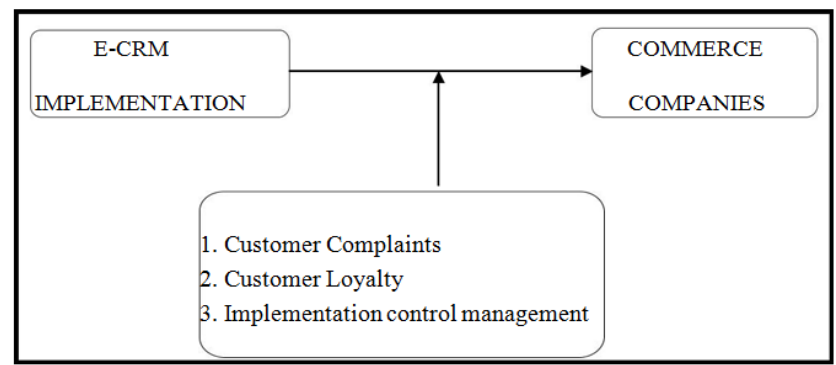

Figure 1. Research Model.

Figure 1. explains that the successful of e-CRM implementation in the e-commerce companies can be seen from the three indicators as follows:

1. Customer Complaint

Customer Complaint Indicator is often used as a benchmark for successful implementation of e-CRM in the ecommerce company. This also supported by Tyrrel \& Woods (2008) which stated customer complaints indicator shows how many customer complaints that often occur at the company's website e-commerce. According to Tyrrel \& Woods (2008), the customer is only allowed to file a complaint directly to the company. However, with a growing era of technology, the company also requires e-complaint so 
that the customer can do complain anywhere and anytime.

2. Customer Loyalty

Customer loyalty indicator determines the performance of the e-CRM implementation in the e-commerce company (Afsar et al. 2010). Consumer behavior will be loyal to a product or service if consumers get greater benefit from the effort expended. The following aspects related to being a benchmark assessment of customer loyalty, such as Customer Satisfication. According to Feinberg and Kadam (2014), customer satisfication become targets to be achieved when eCRM implemented. Some indicator that determines benchmark of customer satisfication are the willingness of the customer to provide a review of the shopping experience in a store, recommend the goods / services to people nearby, the intensity of the customer to shop in the store, as well as the experience of the customer at the time of filing a complaint with the services or products / services received.

3. Implementation control management e-CRM

Implementation control management e-CRM indicator is used to see how the surveillance conducted by the ecommerce company on e-CRM implementation. According to Al-Momani and Noor (2009) explains that assessment aspects of the e-CRM implementation includes e-Service Quality, Easy of Use (Website Interface), and Usability.

\section{Discussion}

As discussed in the previous section about analysis models, the success factor list the resulting from the study in Figure 1. This chapter describes the results of research conducted by previous researchers regarding what factors are affecting the successful implementation of e-CRM in the e-commerce company, the following explanation is based on variables used.

\subsection{Customer Complaint Indicator}

Customer complaints became one of the problems is greatly feared by the company because if the consumer's handling was not maximum, it can change the behavior of consumers who initially loyal becomes disloyal to use the product. According to Cho et al. (2002), handling customer complaints should be included as a key component of e-CRM. Major online customer complaints and dissatisfication have been generated from the problems with Web Customer Service Centers. Cho et al. (2002) research using direct and indirect indicator of customer complaint in a e-commerce company. This result of Cho et al. (2002), has implications for how e-businesses' customer service centers should effectively manage customer complaints. Based on these studies, e-commerce company must manage customer complaint handling system with the implementation of e$\mathrm{CRM}$, for example, by an increase in customer care that is expected to increase customer satisfaction and loyalty.

\subsection{Customer Loyalty Indicator}

In accordance with the objective of e-CRM system to enable companies maintaining good relations with serve customers optimally, then customer loyalty can be used as a reference to see the successful implementation of e-CRM in a company, particularly the e-commerce. Farhadi et al. (2012) explains that some aspects of the customer loyalty indicators such as customer satisfaction and legal undertaking (company already incorporated), positively affect on customer loyalty in buying an item or service. In addition, other research by Lee-Kelley et al. (2003) explains that eCRM can directly improve loyalty of the internet customers. Two previous studies proved that e-CRM implementation is done by a company especially e-commerce bring a positive impact on the customer's decision to purchase an item. This is also supported by the fact that the customer today is more like reading a review of the people experience when shopping to know the quality of products and services offered rather than thinking about the price paid to acquire the product. This statement is supported by Lee-Kelley et al. (2003), since price sensitivity may not be the governing factor that describes how a customer chooses to make a purchase other factors such as security and trust as well as service quality attributes, such as speed and convenience, could be incorporated into the e-retailer's e-CRM Strategy.

\subsection{Implementation Control Management e-CRM}

According to Schoder \& Madeja (2004), the successful implementation of e-CRM is by e-commerce is strongly influenced by company size, type of business, as well as the ability of the management company itself. The study explains that the larger scale of business, the ability of the company management feels quite qualified to undertake the implementation of e-CRM. Schoder \& Madeja (2004) find that the implementation of e-CRM in the company's-based small-medium e-commerce company are still not running well. This is because the company's management are unable to leverage their manager's competence in e-CRM in order to increase their success in electronic e-commerce. Other else, employees a job description for implementing and overseeing the passage of e-CRM, are also forced to work another job description, such as marketing, meeting with clients. In addition, the small-medium e-commerce company focus is still oriented to the sale and have not yet planning to keep a good relationship with the customer after post-purchase occurs.

For the e-CRM implementation based on the type of ecommerce businesses are run, companies with business type $\mathrm{B} 2 \mathrm{C}$ rated better in implementing e-CRM procedures than companies based B2B (Schoder \& Madeja 2004). This finding can be understood from comparing the customer structure in each segment, there are: (1) B2C customers is usually shop for their own account, trying to satisfy several needs from shopping while B2B customers purchase for their companies, as a part of their job so to purchase must according to guidelines determined by their organization and the buying decisions are less flexible; (2) In the B2C segment, the customer is always an individual consumer, whereas a $\mathrm{B} 2 \mathrm{~B}$ customer is usually an organization comprising several 
persons; (3) A typical B2B customer may be more difficult to target individually than a B2C customer; and (4) privacy issues.

Based on meta-analyzes that have been made to map out what are the indicators that a benchmark of success in the eCRM implementation in e-commerce company, no relevant journal that combines the three indicators above to do a thorough investigation. This journal only summarizes the results of any previous journal about whether one of the three indicators above becomes one of determining the successful implementation of e-CRM in the e-commerce company.

However, to see how the three indicators can determine the success of e-CRM implementation in the e-commerce company, an analogy is made to explain their interconnectedness to one another. In e-commerce company, the business process they run is to sell products, in the form of goods and services to customers online in a web media. When a consumer has decided to buy an item on the company, something that is often forgotten by every ecommerce company is customer satisfaction in shopping. Customer satisfaction will be fulfilled if the customer feels the products obtained according to the needs and descriptions that have been described on the web, good delivery speed, responsive customer service, and competitive prices. At the moment when the consumer does not get an indicator that becomes a customer satisfaction requirement, a complaint arises.

Speaking of customer complaints, this can be a serious problem when it is not handled properly by an e-commerce company. The number of customer complaints in an ecommerce company can be seen from the poor reviews given to customers about the shopping experience at that company. Poor reviews given from other customers greatly influence the decision of prospective customers who will shop at the ecommerce company. To solve the problem of the company's relationship with the customer, the need for "After Sales Service" that is included in the implementation of e-CRM can make the customer will consider to buy the same goods in that company and finally can create customer loyalty.

When it comes to successful E-CRM implementation, companies need careful planning, such as providing job description education to employees of the e-CRM division with example: providing solutions to every problem that consumers experience, reporting to the company about customer reviews in shopping experience on e-commerce website and observing consumer behavior in shopping so it can be an input for company strategy in improving service to consumer. Supervision conducted by management in the implementation of e-CRM becomes a benchmark against the company's consistency in maintaining good relationships with consumers.

\section{Conclusion}

Research of the successful implementation of e-CRM in ecommerce website has always been an interesting topic to discuss. The results of this study can be used as an evaluation, as well as the company reference to improve service to the customer company. Based on description in the discussion chapter, it can be concluded that almost all e-commerce companies have implemented e-CRM which is part of the service to enable customers to interact with companies. However, in some previous studies explaining that some ecommerce companies have not implemented the e-CRM optimally. Some constraints faced such as the lack of manpower, inadequate infrastructure systems, as well as lack of control and evaluation of the e-CRM implementation are the cause of many complaints on the e-commerce company still receive. These complaints caused a decline in customer satisfaction levels that affect customer loyalty to purchase goods in that e-commerce.

In this study, the company can improve its services, especially in the field of customer care by increasing the amount of labor to find out the main problems that occur, as well as increase the speed of the handling of customer complaints. In addition, companies also need to improve infrastructure, particularly the e-commerce website to fix the bug problems and the slow pace of time that takes to use the website. Evaluation occurs not only in terms of service to customer care, but also must improve oversight of quality control of a product that is expected to minimize customer complaints occur.

\section{References}

[1] Ahmad, S. (2002). Service failures and customer defection: a closer look at online shopping experiences. Managing Service Quality: An International Journal.

[2] Afsar, B. (2010). Determinants of Customer Loyalty and Proposing Customer Loyalty Model for Banking Sector of Pakistan. Journal Management \& Marketing-Craiova, 12.

[3] Bryan Tyrrell, Robert Woods. (2008). E-Complaint, Lesson to be Learned from the Service Recovery Literature. Journal Travel \& Marketing, 10 .

[4] Beomsoo Shim, Keunho Choi and Yongmoo Suh. (2012). CRM Strategies for a Small-sized Online Shopping Mall based on Association Rules and Sequential Patterns. Expert System with Application 39.

[5] Billy Bai, Rob Law and Ivan Wen. (2008). The Impact of Website Quality on Customer Satisfication and Purchase Intentions: Evidence from Chinese Online Visitors. International Journal of Hospitality Management.

[6] Bose, R. (2002). Customer Relationship Management: key component of IT success. Industrial Management \& Data System, 89-97.

[7] Christian Homburg \& Andreas Fürst. (2005). How Organizational Complaint Handling Drives Customer Loyalty: An Analysis of the Mechanistic and the Organic Approach. Journal of Marketing.

[8] Detlef Schoder, Nils Madeja. (2004). Is Customer Relationship Management a Success Factor in Electronic Commerce? Journal of Electronic Commerce Research. 
[9] Dewi Rosmala, Falahah, Bakhtiar Dwi Arianto. (2012) Aplikasi Pelayanan dan Keluhan Gangguan Telepon Pelanggan di PT Telekomunikasi Indonesia Tbk (Studi Kasus di Kancatel Xxx). Seminar Nasional Informatika.

[10] Efraim Turban, Ephraim McLean, James Wetherbe. (2004) Information Technology for Management: a. Transforming Organizations in the Digital Economy. John Wiley \& Sons.

[11] Farhad Farhadi, samane Karimi Ghartemani, Hakime Karimi Ghartemani, Jafar Raisi Wastegany. (2012). Analyzing the Effects of e-CRM on customers Loyalty: A case study of Parsmodir Khazar Enterprise. Advanced Research in Economic and Management Sciences (AREMS).

[12] Gwo-Guang Lee and Hsiu-Fen Lin. (2005). Customer Perceptions of E-Service Quality in Online Shopping. International Journal of Retail \& Distribution Management.

[13] Hugh Wilson, Elizabeth Daniel \& Malcolm McDonald. (2010). Factors for Success in Customer Relationship Management (CRM) Systems. Journal of Marketing Management, 193-219.

[14] Injazz J. Chen and Karen Popovich. (2003). Understanding Customer Relationship Management (CRM) People, Process and Technology. Business Process Management.

[15] Kalakota, Ravi dan Robinson, Marcia. (2001). E - Business 2.0 Roadmap For Success. USA: Addison Wesley.

[16] Khalid Al-Momani, Nor Azila Mohd. Noor. (2009). EService Quality, Ease of Use, Usability and Enjoyment as Antecedents of E-CRM Performance: An Empirical Investigation in Jordan Mobile Phone Services. The Asian Journal of Technology Management, 50-63.

[17] Liz Lee-Kelly, David Gilbert, Robin Mannicom. (2008). How e-CRM can Enhance Customer Loyalty. Marketing Intelligence \& Planning, 239-248.

[18] Minjoon Jun, Zhilin Yang, DaeSoo Kim. (2004). Customers' Perceptions of Online Retailing Service Quality and their Satisfication. Kalakota, Ravi dan Robinson, Marcia. 2001. E Business 2.0 Roadmap For Success. Addison - Wesley. USA, 817-840.

[19] Richard Feinberg Rajesh Kadam. (2002). E-CRM Web Service Attributes as Determinants of Customer Satisfaction with Retail Web Sites. International Journal of Service Industry Management, 432 - 451.

[20] Swift, Ronald S. (2000). Accelerating Customer Relationships Using CRM and Relationship Technologies. Upper Saddle River, NJ: Prentice Hall.
[21] Torben Hansen, Ricky Wilke and Judith Zaichkowsky. (2010). Managing Consumer Complaints: Differences and Similarities among Heterogeneous Retailers. International Journal of Retail \& Distribution Management.

[22] Werner Reinartz, Manfred Krafft, And Wayne D. Hoyer. (2004). The Customer Relationship Management Process: Its Measurement and Impact on. Journal of Marketing Research, 293-305.

[23] Wu, I. L. (2013). The Antecedents of Customer Satisfaction and its Link to Complaint Intentions in.

[24] International Journal of Information Management, 166- 176.

[25] Wu, I.-L. (2013). The Antecedents of Customer Satisfication and its Link to Complaint Intentions in Online Shopping: An Integration of Justice, Technology, and Trust. International Journal of Information Management.

[26] Yamin, S., dan Kurniawan, H. (2009). SPSS Complete: Teknik Analisis Statistik Terlengkap dengan.

[27] Software SPSS. Jakarta: Penerbit Salemba Infotek..

[28] Ying-Feng Kuo and Chi-Ming Wu. (2012). Satisfication on Post-Purchase Intentions with Service Ecovery of Online Shopping Websites: Perspective on Perceived Justice and Emotions. International Journal of Information Management.

[29] Yooncheong Cho, Il Im, Roxanne Hiltz, Jerry Fjermestad. (2002). The Effects of Post-Purchase Evaluation Factors on Online Vs. Offline Customer Complaining Behavior: Implications for Customer Loyalty. Advances in Consumer Research, 318-326.

[30] Zaman Ali, Ishaku Ishaya, Haslinda Hassan. (2015). The Critical Success Factors of e-CRM Implementation to Small and Medium Enterprises. International Conference on Ecommerce.

[31] Asosiasi Penyelenggara Jasa Internet Indonesia 2017, Pengguna Internet Di Indonesia Tahun 2016, Asosiasi Penyelenggara Jasa Internet Indonesia, Viewed 25 March 2017, <Www.Apjii.Or.Id $>$.

[32] Badan Pusat Statistik 2017, Badan Pusat Statistik, Jumlah Pelaku E-Commerce Di Indonesia Tahun 2016, Viewed 25 March 2017, <Www.Bps.Go.Id $>$.

[33] Kementerian Keuangan 2017, Roadmap E-Commerce Indonesia, Kementerian Keuangan, Viewed 25 March 2017, $<$ Www.Kemenkeu.Go.Id $>$. 